\title{
A Study on the Effect of Mahaushadhadi Anjanam in Pishtakam
}

\author{
Research Article
}

\section{Krishna Kumar $\mathbf{V}^{1^{*}}$, Abdul Salam A $A^{2}$, Swamy GK ${ }^{3}$}

1. Research Officer (Ayu), Regional Ayurveda Research Institute for Eye Diseases, Lucknow.

2. Professor \& H.O.D, Dept. of Shalakya Thantra, Govt Ayurveda College, Thiruvananthapuram.

3. Assistant Director In-charge, Regional Ayurveda Research Institute for Eye Diseases, Lucknow.

\begin{abstract}
Pishtakam is a disease occurring in the white portion of the eye. It is manifested as a dense white eruption, or as a nodule resembling a water drop. It is a Kapha predominant condition treatable by medical intervention. Pinguecula is a condition resembling Pishtakam. It is an extremely common degenerative condition of the conjunctiva which is characterized by formation of a yellowish white nodule on the bulbar conjunctiva near the limbus. In this study Anjanam which is a medical intervention and a localized Kapha sodhana procedure was taken as the intervention of choice. It was planned to compare the result between Mahaushadhadi Anjanam in Group A study group and Jateemukuladi Anjanam in Group B control group. Mean change in vertical diameter of Pishtakam before treatment and 2 months after treatment in study group was 0.9025 and for control group it was 0.2450 . Mean change in horizontal diameter of Pishtakam before treatment and 2 months after treatment in study group was 0.5325 and for control group it was 0.1900 . No adverse drug reaction was found during whole study. Total 40 patients were registered and from the results and observations it could be concluded that both drugs were effective and the study drug proved to be more significant in comparison to the control drug $(\mathrm{p}=<0.001)$.
\end{abstract}

Keywords: Jateemukuladi Anjanam, Mahaushadhadi Anjanam, Pishtakam, Pinguecula.

\section{Introduction}

Among numerous diseases mentioned by Ayurveda Acharyas relating eye, Pishtakam is one among them affecting the Suklamandala (white portion) of the eye. It is manifested as a dense white eruption, or as a nodule resembling a water drop (1). Based on the clinical features Pishtakam can be correlated to Pinguecula. It is an extremely common, innocuous degenerative condition of the conjunctiva. It is characterized by formation of a yellowish white patch on the bulbar conjunctiva near the limbus. It is commonly seen in outdoor workers and in elderly people. The prevalence of Pinguecula in South Indian population is $11.3 \%$ (2). The complications of Pinguecula include inflammation, intra epithelial abscess formation and conversion to Pterygium. It may affect the person's vision by creating astigmatism. It may become cosmetically undesirable. If cosmetic is a concern surgical excision is sometimes done.

Thus in order to prevent complications, prevent progression into Pterygium and to be used in patients apprehensive to surgery, medical management is essential in Pishtakam. Since it is a Kapha predominant

*Corresponding Author:

Krishna Kumar V

Research Officer (Ayu),

Regional Ayurveda Research Institute for Eye Dis-

eases, Lucknow

E-mail: drkkempran@gmail.com condition (3) treatable by medical intervention (4), Anjanam which is a medical intervention and a localized Kapha sodhana procedure was taken as the intervention of choice. In study group of 20 patients Mahaushadhadi anjanam (5) was given for Anjana therapy for 21 days. The study was conducted in Dept. of Shalakya Thantra, Govt.Ayurveda College Hospital, Thiruvananthapuram. No clinical studies have been conducted on Pishtakam and Mahaushadhadi anjanam till date.

\section{Aims and objectives:}

The present study was based on following aims and objects:

1. To study and understand the etiopathogenesis of Pishtakam (Pinguecula) in Ayurvedic classical literature.

2. To find out the effect of Mahaushadhadi anjanam in Pishtakam.

\section{Materials and methods:}

The study was approved by Institutional Ethics Committee (No. AVC IEC 052615/2012). Patients were selected from the O. P. D. of Dept. of Shalakya Thantra of Govt. Ayurveda College Hospital, Thiruvananthapuram. Patients' written informed consent was taken before starting the treatment. Patients were selected using 'Block Randomization method'. The study was conducted in 40 subjects. 


\section{Diagnostic criteria:}

Criteria for inclusion: Age Control group between 40 to 70 years and having signs of Pishtakam (Pinguecula) According to Ayurvedic Classics as well as Modern science.

Criteria for exclusion: Patients suffering from Pingueculitis, Phlyctenulosis, Nodular episcleritis, Cysts of the conjunctiva, Patients who are contraindicated for Anjanam, Psychic and non co-operative patients were excluded.

\section{Grouping: \\ Group A-Study group \\ Group B-Control group}

\section{Intervention:}

Before doing Anjanam, both groups were given Snehapana with plain cow's ghee 10 gm for 3 days followed by Virechanam with Gandharva Erandam (15$30 \mathrm{ml}$ ). Further Nasyam with Anutailam (5ml) was done for another 5 days.

\section{Group A-Study group:}

Anjanam was done with Mahaushadhadi anjanam for 21 days in the morning. Choorna (powder) of Mahaushadham (Zingiber officinale), Magadhika (Piper longum Linn), Mustha (Cyperus rotundus Linn), Saindavam(Rock salt) and Suklamaricha (Moringa olifera Lam-seeds)were taken in equal quantity by weight. Required quantity of mathulunga swarasa (juice of Citrus medica Linn) was added to the mixture and pounded well to get rasakriya( paste) form. Harenu matra $(\sim 50 \mathrm{mg}$ ) was applied in the lower fornix of the eyes using a Salaka.

\section{Group B-Control group:}

Anjanam was done with Jateemukuladi Anjanam (6) for 21 days in the morning. Jateemukuladi varti was pounded with honey to get rasakriya( paste) form. Harenu matra ( $50 \mathrm{mg})$ was applied in the lower fornix of the eyes using a Salaka.

\section{Investigations:}

Routine hematological and urine analysis were carried out before treatment to rule out any systemic diseases.

\section{Parameters for assessment:}

Recording of vertical diameter and horizontal diameter of Pishtakam was done before and after Anjana therapy in each group using Vernier calipers. The results were assessed after 30 days of treatment, so as to observe and record the changes occurred. Follow up was done 1 month, and 2 months, after the treatment to observe how long the changes last and assess the effectiveness of treatment.

\section{Statistical estimation of results:}

The obtained data were analyzed statistically. Statistical derivations like mean, standard deviation and percentage were computed for statistical evaluation. By using paired " $t$ " test before and after treatment effect were done separately for both study and control group of patients. The drug which is more effective was analysed using the student " $t$ " test for both groups.

\section{Observations and Results :}

In this clinical trial of Pishtakam, a total number of 40 patients were registered and were randomly distributed into two groups. 20 patients registered in each group. The general observations are shown in Figure-1

Observations regarding laterality of Pishtakam revealed that, $75 \%$ of patients had Pishtakam in unilateral nasal side, $22.5 \%$ in bilateral nasal side, $2.5 \%$ in unilateral temporal side, and none of the patients had Pishtakam in bilateral temporal side, which is identical to the textual reference of Pinguecula. Observations regarding duration showed that, $20 \%$ of patients noticed Pishtakam within 6 months, $45 \%$ within 1 year, $22.5 \%$ within 2 years and $12.5 \%$ of patients within 3 years. This suggests the chronic nature of the disease.

While observing the age of patients, $7.5 \%$ were between 41-50 years, 32.5\% between 51-60 years and $60 \%$ between $61-70$ years of age. Thus it is evident that Pishtakam is more in old age as it is a degenerative disease. Observing Prakrithi of patients, the incidence was more in Vathakapha Prakrithi $42.5 \%$ who had more chance to develop the disease as the aetiological factors affect them more, followed by Pitha kapha Prakrithi 37.5\% and Vatapitta Prakrithi $20 \%$. Regarding the status of Agni, 60\% of patients were mandagni, $7.5 \%$ theekshnagni, $12.5 \%$ vishamagni and 20\% samagni. Patients with mandagni had more chance of getting Pinguecula. Apathyaharas lead to agnimandya and amadosha. Improper Agni will cause creation of gunaheena dhathus and leads to malnourishment resulting in the formation of disease.

The occupational status of patients showed that Pinguecula is more in those who work outdoor 50\% and $32.5 \%$ of patients were housewives who were using the conventional type of chimneys for cooking. $17.5 \%$ of patients were indoor workers. Thus working environment plays major role in producing Pishtakam. Observing the habit, exogenous factors had great influence in the manifestation of Pinguecula. The incidence was more among persons who were exposed to sunlight $25 \%$. UV radiation causes degenerative changes in the conjunctiva accounts for this. Frequent exposure to dry and hot wind also leads to degenerative changes in conjunctiva played the second role in the manifestation of disease $25 \%$. Exposure to soot was the third factor $17.5 \%$ which occurred in persons using the conventional chimneys. The carbon particles in this soot had a great influence in degenerative changes in conjunctiva. Smoke also produced the same changes in the conjunctiva and lead to disease in $17.5 \%$. Prolonged journey also played a role in the manifestation of disease in $15 \%$. Due to overindulgence of external factors like wind, smoke, dust, allergens etc Vatha gets vitiated in the eyes and it suits that in Madhava Nidana, Pishtakam is said to be Kapha-Vata in nature.(7) 


\section{Effect of therapy:}

The reduction in lowering the vertical diameter of Pishtakam is seen to be statistically significant $(\mathrm{p}<0.001)$ in study group. The lowering of reduction obtained in the follow up also shows that the study is statistically significant $(\mathrm{p}<0.001)$ in study group. (Table1) The reduction in length of Pishtakam seen is statistically significant $(\mathrm{p}<0.001)$ in control group also. The lowering of length of Pishtakam obtained in the follow up were also statistically significant $(p<0.001)$ in control group (Table-2). Mean change in vertical diameter of Pishtakam before treatment and 2 months after treatment in study group was 0.9025 and for control group it was 0.2450 . This difference was statistically significant. The study drug was more effective than control drug in lowering the vertical diameter of Pishtakam 2 months after treatment (Table-3)

The reduction in lowering the horizontal diameter of Pishtakam is seen to be statistically significant $(p<0.001)$ in study group. The lowering of reduction obtained in the follow up also shows that the study is statistically significant $(\mathrm{p}<0.001) \quad($ Table-4). The reduction in horizontal diameter of Pishtakam seen was statistically significant $(\mathrm{p}<0.001)$ in control group also. The lowering of horizontal diameter of Pishtakam obtained in the follow up was also statistically significant $(p<0.001)$ in control group (Table-5). Mean change in horizontal diameter of Pishtakam before treatment and 2 months after treatment in study group was 0.5325 and for control group it was 0.1900. This difference was statistically significant. The study drug was more effective than control drug in lowering the horizontal diameter of Pishtakam 2 months after treatment (Table-6).

Thus it is evident that both drugs were effective and the study drug proved to be more significant in comparison to the control drug $(\mathrm{p}=<0.001)$.

\section{Probable Mode of action:}

Mahaushadhadi anjanam which is said to be "Pishtakamasu hanyad" is mentioned in the classical text Susrutha Samhitha Uttarathantra Sleshmabhisyanda Pratishedha. The ingredients of this anjanam are Mahaushadham, Magadhika, Mustha, Saindavam and Suklamaricha. Most of the ingredients in the anjana are katu, tikta rasa and usna veerya and thus perform the function of Lekhanam ( Scarify). Most of the drugs are kapha Vatha hara and these dosas have importance in the Samprapthi of the disease. Thus the action of medicine is not due to the single drug effect but due to the combined effect after samskara. All the medicines in this Anjana are Lekhanam and Chakshushya ( congenial to eye) in nature. Mahaushddhadi anjanam flushes out the debris and unwanted tissues performing the function of Lekhanam.(8) All drugs are Chakshushya, thus protecting the normal tissues of the eyeball from excessive scraping.

\section{Conclusion:}

Based on clinical presentation Pishtakam can be correlated to pinguecula. The incidence of Pishtakam is more among old age group. The patients with Vathakapha prakrithi are seen more affected with Pishtakam. The study drug Mahaushadhadi Anjanam is more effective than control drug Jateemukuladi Anjanam in preventing the progression of Pishtakam.

\section{References:}

1. Susrutha, Susruta Samhita, Uttara Thantra, 4/7, Reprint, Varanasi: Chaukhamba Sanskrit Sansthan, 2010, p.601

2. Asokan R, Venkatasubbu RS, Velumuri $\underline{L}$, Lingam $\mathrm{V}$, George $\mathrm{R}$. Prevalence and associated factors for pterygium and pinguecula in a South Indian population.

3. Ophthalmic Physiol Opt. 2012 Jan;32(1):39-44. doi: 10.1111/j.1475-1313.2011.00882.x. Epub 2011 Nov 24.

4. Susrutha, Susruta Samhita, Uttara Thantra, 1/34, Reprint, Varanasi: Chaukhamba Sanskrit Sansthan, 2010, p.598

5. Susrutha, Susruta Samhita, Uttara Thantra, 8/910, Reprint, Varanasi: Chaukhamba Sanskrit Sansthan, 2010, p.610

6. Susrutha, Susruta Samhita, Uttara Thantra, 11/13, Reprint, Varanasi: Chaukhamba Sanskrit Sansthan, 2010, p.615

7. Vagbhata, Astanga Hridaya, Uttara Sthana, 11/9, Reprint, Varanasi: Chaukhamba Sanskrit Sansthan, 2011, p.812

8. Madhavakara, Madhava Nidana, Uttarardha, 51/68, Reprint, Varanasi: Chaukhamba Sanskrit Sansthan, 2011, p.431

9. Sharangadhara acharya, Sharangadhara Samhita, Prathama Khanda, 4/10, First edition, Varanasi: Chaukhamba Sanskrit Sansthan, 2006, p.37

Figure- 1: General Observations $(n=40): \%$

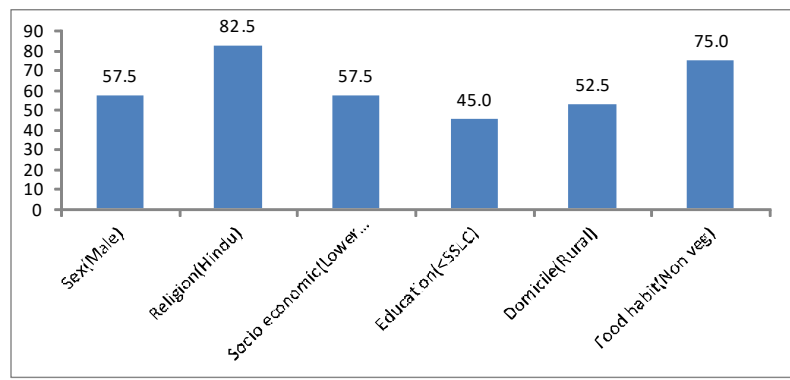


Table-1 Analysis of effectiveness of treatment in lowering the vertical diameter of Pishtakam in study group

\begin{tabular}{|l|l|l|l|l|l|}
\hline \multicolumn{1}{|c|}{ Analyzing stage } & \multicolumn{1}{c|}{ Mean } & \multicolumn{1}{c|}{ SD } & Study Group & Paired "t $t$ " & P value \\
\hline BT & 1.825 & 0.712 & & & \\
\hline AT & 1.538 & 0.722 & BT-AT & 3.708 & 0.001 \\
\hline MONTH & 1.2 & 0.615 & BT-1M & 11.180 & $<0.001$ \\
\hline 2 MONTH & 0.763 & 0.417 & BT-2M & 9.920 & $<0.001$ \\
\hline & & & AT-1M & 4.613 & $<0.001$ \\
\hline & & & AT-2M & 7.450 & $<0.001$ \\
\hline & & & $1 \mathrm{M}-2 \mathrm{M}$ & 5.552 & $<0.001$ \\
\hline
\end{tabular}

Table-2 Analysis of effectiveness of lowering the vertical diameter of Pishtak am in control group during the treatment

\begin{tabular}{|l|l|l|l|l|l|}
\hline Analyzing stage & Mean & SD & Control Group & Paired "t" & P value \\
\hline BT & 2.390 & 0.1944 & & & \\
\hline AT & 2.285 & 0.2059 & BT Vs AT & 4.972 & $<0.001$ \\
\hline 1 MONTH & 2.195 & 0.1791 & BT Vs 1M & 10.563 & $<0.001$ \\
\hline 2 MONTH & 2.145 & 0.1959 & BT Vs 2M & 10.434 & $<0.001$ \\
\hline
\end{tabular}

Table-3 Comparison of effect of change in vertical diameter of Pishtak am in study group and control group before treatment and 2 month after the treatment

\begin{tabular}{|l|l|l|l|l|l|}
\hline Column & Size & Mean & Standard Deviation & "t" value & P value \\
\hline Study group BT - 2M after Treatment & 20 & 0.9025 & 0.28584 & 9.656 & 0.000 \\
\cline { 1 - 3 } Control group BT - 2M after Treatment & 20 & 0.2450 & 0.10501 & & $(<0.001)$ \\
\hline
\end{tabular}

Table-4 Analysis of effectiveness of treatment in lowering the horizontal diameter of Pishtakam in study group of patients

\begin{tabular}{|l|c|c|c|c|c|}
\hline \multicolumn{1}{|c|}{ Analyzing stage } & Mean & SD & Study Group & Paired "t" & P value \\
\hline BT & 1.950 & 0.560 & & & \\
\hline AT & 1.500 & 0.649 & BT-AT & 5.604 & $<0.001$ \\
\hline $1 \mathrm{MONTH}$ & 1.113 & 0.535 & BT-1M & 10.011 & $<0.001$ \\
\hline $2 \mathrm{MONTH}$ & 0.813 & 0.486 & BT-2M & 14.591 & $<0.001$ \\
\hline & & & AT-1M & 5.820 & $<0.001$ \\
\hline & & & AT-2M & 8.966 & $<0.001$ \\
\hline & & & $1 \mathrm{M}-2 \mathrm{M}$ & 5.080 & $<0.001$ \\
\hline
\end{tabular}

Table-5 Analysis of effectiveness of lowering the horizontal diameter in control group during the treatment

\begin{tabular}{|l|c|c|c|c|c|}
\hline Analysing stage & Mean & SD & Control Group & Paired "t" & P value \\
\hline BT & 1.550 & 0.1960 & & & \\
\hline AT & 1.490 & 0.1881 & BT Vs AT & 3.559 & $<0.001$ \\
\hline 1MONTH & 1.405 & 0.1986 & BT Vs 1M & 7.855 & $<0.001$ \\
\hline 2MONTH & 1.360 & 0.2317 & BT Vs 2M & 9.970 & $<0.001$ \\
\hline
\end{tabular}

Table-6 Comparison of effect of change in horizontal diam eter of Pishtakam in study group and control group before treatment and 2 month after the treatment

\begin{tabular}{|l|l|l|l|l|l|}
\hline Column & Size & Mean & Standard Deviation & "t" value & P value \\
\cline { 1 - 4 } Study group BT-2M after Treatment & 20 & 0.5325 & 0.10794 & 11.137 & 0.000 \\
Control group BT-2M after Treatment & 20 & 0.1900 & 0.08522 & & $(<0.001)$ \\
\hline
\end{tabular}

